\title{
Renewable Energy in Morocco: Assessing risks to avoid a resource curse
}

Aniq Ahsan ( $\nabla$ aniq.ahsan@stx.ox.ac.uk)

University of Oxford

Alycia Leonard ( $\square$ alycia.leonard@eng.ox.ac.uk)

University of Oxford

Flora Charbonnier

University of Oxford

\section{Stephanie Hirmer}

University of Oxford https://orcid.org/0000-0001-7628-9259

\section{Short Report}

Keywords: Morocco, Resource Curse, Renewable Energy, Green Transition, Policy Objectives

Posted Date: October 29th, 2021

DOI: https://doi.org/10.21203/rs.3.rs-1010915/v2

License: @ (i) This work is licensed under a Creative Commons Attribution 4.0 International License. Read Full License 


\begin{tabular}{|c|c|c|c|}
\hline ( & 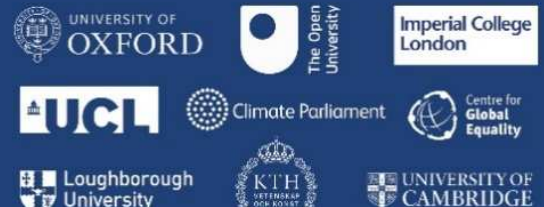 & $\begin{array}{l}\text { The views expressed in this } \\
\text { document are informal and do } \\
\text { not necessarily reflect the UK } \\
\text { government's official policies. }\end{array}$ & UKaid \\
\hline
\end{tabular}

\title{
Renewable Energy in Morocco: Assessing risks to avoid a resource curse
}

\author{
Aniq Ahsan, Alycia Leonard, Flora Charbonnier, and Stephanie Hirmer
}

\section{Key Messages}

- We evaluate 14 potential risks which could cause renewable energy development in Morocco to provoke a resource curse.

- We identify the biggest risks to be economic dependence, technical dependence, and damage to flora and fauna.

- Policy objectives are identified to prevent/mitigate these risks. These are: careful negotiation of robust co-funding arrangements to safeguard Moroccan autonomy; the development of local renewable energy technology capabilities; and continuation and enhancement of environmental protection mandates.

\section{Introd uction}

In this briefing we evaluate the risk of renewable energy (RE) development provoking a resource curse in Morocco and identify policy objectives which convert risks into development opportunities.

RE is a huge opportunity for economic and social development in Morocco. Morocco has high solar and wind potentials [2] and interconnections throughout North Africa and Europe. High-Income Countries (HICs) are increasingly looking to Low- and Middle-Income Countries (LMICs) with RE resources to import low-carbon energy. This creates a great opportunity for Morocco to combat climate change while creating economic and social benefits. However, there are risks to RE development which could turn this opportunity into a resource curse.

A resource curse occurs when a resource-abundant country paradoxically grows more slowly than resource-poor counterparts [3]. It can provoke a host of negative social and economic "symptoms". The curse is traditionally prompted by subsoil resources (e.g., oil, minerals). However, with a boom of RE development on the horizon - as many HICs (e.g., Germany) [4] look at Morocco to provide their energy needs - it

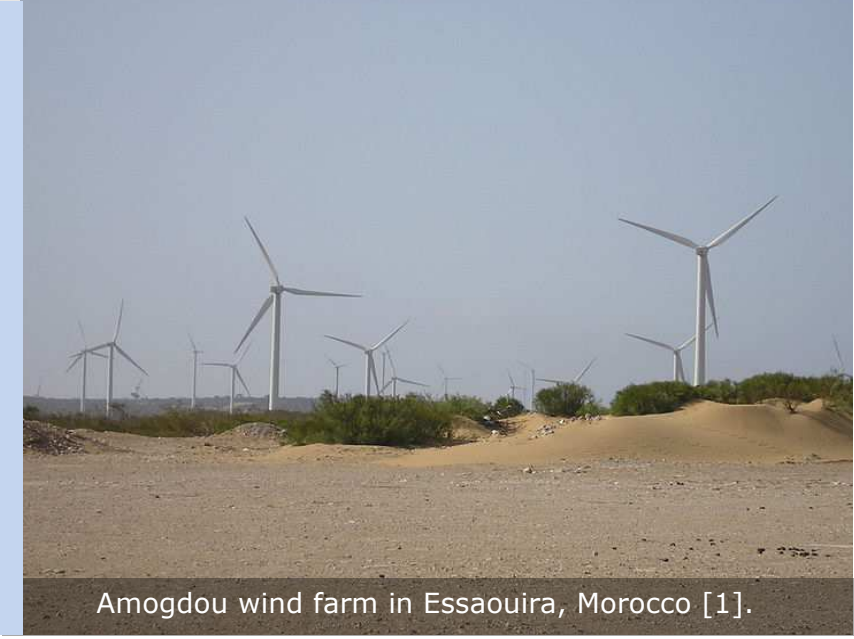

is important to assess risk factors for a RE-based resource curse.

\section{Methods}

We first examined the typical symptoms of resource curses and identified fourteen relevant to RE development (listed in Figure 1) through literature review. We subsequently used key informant surveys to identify which symptoms are likely to be particularly highrisk as RE is further developed in Morocco. Respondents were asked to classify the likelihood of each on a 5 -point scale (very unlikely to very likely), and rank the symptoms from highest to lowest potential impact. Twenty-one key informants from a variety of backgrounds (see Figure 2) took part ${ }^{1}$.

The mean likelihood score and impact ranking for each symptom were rescaled to a relative value between 0 and 1 corresponding to minimum and maximum likelihood and impact respectively (see Figure 1). Only symptoms with high likelihood and impact are discussed here; the full paper will go into further detail. Follow-up interviews with ten key informants were used to understand existing policies and assess potential options. Anonymous interview excerpts are inserted to support assertions in the text ${ }^{2}$.

\footnotetext{
${ }^{1}$ Not all participants answered all survey questions, including questions regarding work experience levels.

${ }^{2}$ Interviews were conducted in English or French based on the interviewee's preference. All quotes have been translated to English by the research team.
} 


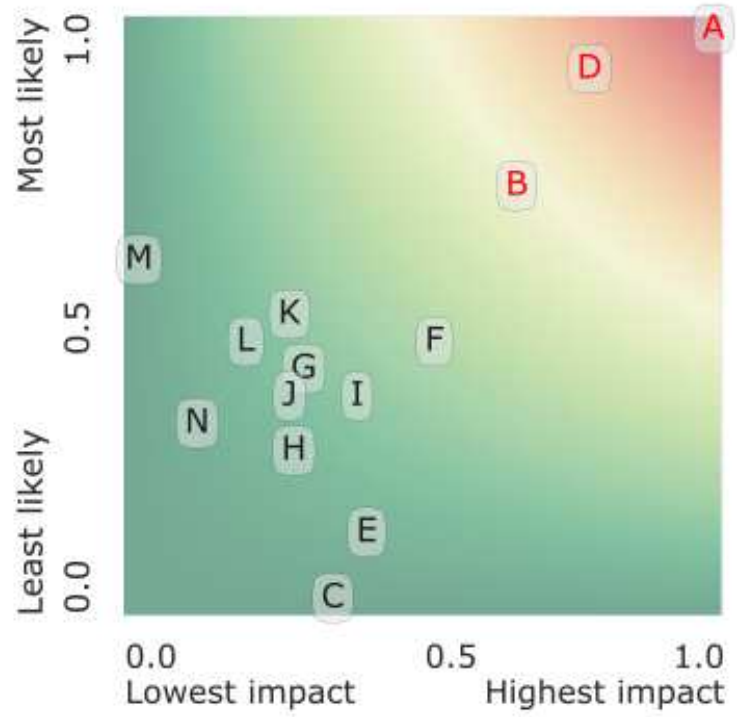

A. Increased economic dependence on other countries and IOs.

B. Damage to local flora, fauna, and landscape.

C. Heightening of tensions and conflicts.

D. Increased dependence on other countries for technologies/expertise.

E. Diversion of land for generation of RE.

F. Increased occurrences of land grabs.

G. Loss of competitiveness of other export sectors ("Dutch Disease").

$\mathrm{H}$. Increased income volatility and trade imbalance.

I. Reduced economic diversity.

J. Weakening of institutions.

$\mathrm{K}$. Increased income inequality between wage and non-wage earners.

L. Increase in expats dominating high-income and/or high-skilled jobs.

$M$. Diversion of talent from other sectors to RE due to higher wages.

N. Diversion of investments from human capital towards RE.

Figure 1: Risk analysis for RE-related resource curse symptoms in Morocco. Symptoms in the top right corner have the highest likelihood and potential impact. The $x$ - and $y$-axes denote a score relative to other symptoms, as evaluated by the key informants presented in Figure 2. In red are the three symptoms with the highest likelihood and impact consensus. IO: international organisation. RE: renewable energy.

\section{Results}

We find the following three resource curse symptoms to have the highest likelihood consensus and impact: (1) economic dependence, (2) technical dependence, and (3) damage to flora and fauna. This is illustrated in Figure 1. Details on each follow.

\section{1) Economic dependence}

The funding of RE developments can create economic dependence on other countries and international organizations (IOs). Most Moroccan RE projects are cofunded by the government and IOs or banks, in arrangements facilitated by the Moroccan Agency for Sustainable Energy (MASEN) [5]. Morocco has historically taken loans from various IOs (e.g., \$237 million from the Arab Fund for Economic and Social Development [6]). If Morocco funds RE projects using loans, it could become economically dependent on other countries or IOs. As RE is likely to be a large source of income and a big job creator, the welfare of Morocco's people may also rely on these investments.

"Renewable energy projects in Morocco are partially financed by international banks, partially financed by the Moroccan state. There is a risk of misappropriation of Moroccan state finances. Funding for infrastructure, social projects and health could be diverted." (I3)

Given the stiff competition between countries and projects for RE investments, there is a heightened power imbalance between investors and countries like Morocco. This creates the risk of being subject to political influence resulting from economic dependence.

"When you are not a superpower, you cannot claim that national policy is not influenced by foreign policy" (I5)
While foreign capital has the potential to interfere with Moroccan autonomy, there is an appreciation of neocolonial risks. Moroccan NGOs [7], for instance, have been able to maintain their autonomy by choosing their funders. Our key informants share these sentiments about Moroccan RE development:

"There is no longer capital rule as in oil countries (in the $20^{\text {th }}$ century), when you could do what you want. There is a spirit of the $21^{\text {st }}$ century. In Morocco, it is no longer possible for capital to arrive and dominate; we no longer accept this." (I2)

\section{2) Technical dependence}

RE development can provoke increased dependence on other countries for RE technologies and expertise. While Morocco has existing research institutions and community enthusiasm for RE developments [8], it has less capacity for technology manufacturing [9]. This has led to some dependence on external companies which manufacture Morocco's RE technologies:

\footnotetext{
"The government had policies for industrial integration, but they have failed to live up to expectations. There was supposed to be a transfer of technology between external companies and Moroccan companies. However, large international companies were brought in to build solar power plants almost as if it was a transaction. Moroccan companies did not really learn deep technological skills. Local companies were able to learn and perform less specialized and technical jobs, or 'supporting' jobs." (I1)
}

Technological dependence has historically been an issue for LMICs [10]. There is a spectrum of capability deficits, ranging from LMICs only having capabilities in operations and maintenance through to more 
extensive capabilities in independent innovation and product development (see [11]). Technological dependency can be seen, for instance, in Chinese nuclear technology in Pakistan [12] and infrastructural developments throughout Africa [13].

For Morocco, the development of in-country RE technology manufacturing capacity can turn this risk into an economic opportunity. This may also require improvements in sectors like education.

"We don't have the expertise and the technology ... technology and industrial integration remains limited, even though it is increasing. We have real problems in research and the education system in Morocco, and in the integration between research and the business world. We are trying to change this situation, but it will not be done in one year." (I8)
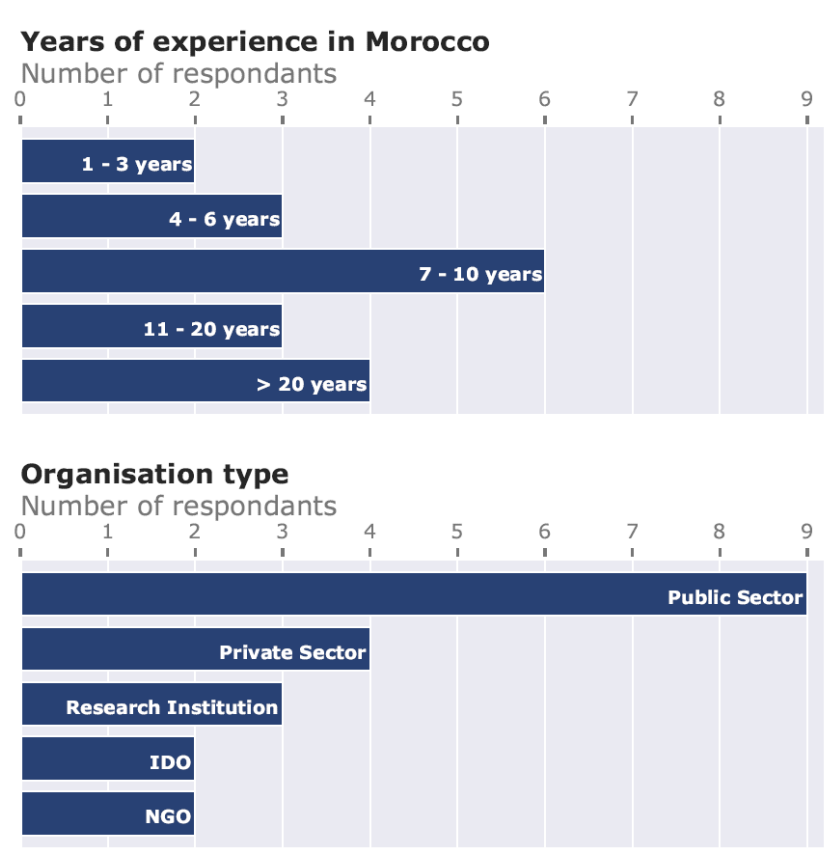

Figure 2: Work experience levels and occupations of the key informants who participated in the survey ${ }^{1}$.

\section{3) Damage to local flora and fauna}

The development of RE infrastructure can cause environmental degradation [14] and habitat loss [15]. Spill-over effects of RE production along the supply chain can have severe biodiversity impacts $[16$, p.6]: "generating the required technologies and infrastructure will drive an increase in the production of many metals, creating new mining threats for biodiversity". While the mining of materials for RE technologies is likely to be primarily carried out in other countries rather than Morocco itself, the development of in-country RE farms still holds risk to flora and fauna.

Though the deserts and mountains often used for wind and solar development in Morocco are commonly seen as unproductive land ideal to exploit [17], they are a valuable part of the natural world. Moreover, Morocco is home to nomadic pastoralists whose traditional land-based knowledge [18] could be threatened by RE development.

"Zero risk doesn't exist, there will be an impact [on the ecosystem]. However, we do not work blindly. ... The desert is not entirely deserted." (I2)

Additionally, Morocco has water scarcity which RE could worsen. Exploitation of the environment has been observed in Moroccan mining [19]. Similar exploitation could be replicated in RE.

Environmental Impact Assessment is typically required for Moroccan RE projects by either IO funders [e.g., 20] or regional investment centres. Morocco has strong policies on water use, from law 10-95 [21] to the National Water Plan [22]. Nevertheless, the policies could still be strengthened and better enforced. Key informants highlighted that there can be win-win situations for local populations by designing RE developments that account for water scarcity:

"We do care about our environment. It's the only asset we have for these kind of business models. ... Water makes living creatures live, but also makes industry live. In Morocco, we have water scarcity in some regions. Unfortunately, those are also the best locations for these plants. In this case, the mitigation is desalination. ... The ocean is really very convenient for this. We can oversize the desalination capacity to provide water for local communities and agriculture. " (I4)

\section{Recommendations}

To prevent and mitigate these high-risk resource curse symptoms for renewable energy (RE) in Morocco, the following policy objectives are recommended.

\section{1) Negotiate robust co-funding agreements to safeguard long-term growth and autonomy.}

Morocco should seek multiple co-funders, ensure those co-funders are politically neutral, and negotiate mutually beneficial terms. This will minimize the influence of any one foreign entity in Morocco. Robust funding agreements can help to ensure that only Moroccan state funds allocated to RE are used, preventing any fund diversion from other social portfolios.

\section{2) Develop innovation capabilities for RE.}

This will not only reduce Morocco's reliance on foreign entities for state-of-the-art RE technologies, but also generate high value jobs in Morocco. Improving manufacturing and test-bedding capabilities could create many jobs. Building innovation capabilities in firms, universities, and other institutions can also allow Moroccan companies to grow independently.

\section{3) Continue, strengthen, incentivize, and en- force Environmental Impact Assessment.}

Solar and wind currently accounts for about $13 \%$ of Morocco's domestic electricity supply [23]. The Moroccan Agency for Sustainable Energy's (MASEN) 
mandates have been successful in minimizing environmental impact and land-use conflict due to RE in Morocco. However, RE production in Morocco could increase by orders of magnitude as it increasingly

\section{References}

1. Flickr. (2017). Amogdoul Wind Farm, Essaouira, Morocco. Accessed 2021-08-27: https://commons. wikimedia.org/wiki/File:Amogdoul Wind Farm Essaouira 2007.jpg

2. Pfenninger, S. \& Staffell, I. (2021) Renewables.ninja. Accessed 2021-08-31: www.renewables.ninja

3. Sachs, J. D., \& Warner, A. M. (2001). The curse of natural resources. European economic review, 45(4-6), 827-838.

4. Sanz, A. (2021, May 31). Morocco halts green hydrogen agreement with Germany. Atalayar. https://atalayar.com/en/content/morocco-halts-green-hydrogenagreement-germany

5. Whitley, S., \& Granoff, D. (2014). The Moroccan Agency for Solar Energy and the Moroccan Solar Plan. Green Growth Best Practice (GGBP). https://www.greengrowthknowledge.org/case-studies/moroccan-agencysolar-energy-and-moroccan-solar-plan

6. Arab Fund for Social and Economic Development (AFESD). (2020) Latest Projects: Loans to help Finance Two Projects in Morocco. https://www.arabfund.org/Default. aspx?pageid $=487 \&$ nid $=658$

7. Patel, N. (2017). "Aiding Neocolonialism? Moroccan NGOs, International Actors, and Questions of Autonomy in Human Rights Advocacy" Independent Study Project (ISP) Collection. 2673. https://digitalcollections.sit.edu/isp collection/2673

8. Hanger, S., Komendantova, N., Schinke, B., Zejli, D., Ihlal, A., \& Patt, A. (2016). Community acceptance of large-scale solar energy installations in developing countries: Evidence from Morocco. Energy Research \& Social Science, 14, 80-89. https://doi.org/10.1016/j.erss.2016.01.010

9. Kost, C., et al. (2012). "Solar Technologies in Morocco, Industry and Value Chain Assessment Support for the Moroccan Solar Plan." https://www.giz.de/de/downloads/giz2012-en-solar-plan-morocco.pdf

10. Patel, S. J. (1974). "The technological dependence of developing countries." The Journal of Modern African Studies 12.1, 1-18. https://doi.org/10.1017/S0022278X00008946

11. Bell, M. (2009) Innovation Capabilities and Directions of Development, STEPS Working Paper 33, Brighton: STEPS Centre. https://opendocs.ids.ac.uk/opendocs/handle/20.500.12413/2457

12. Gul, A. (2021, March 19). Pakistan's China-Built Nuclear Reactor Starts Operation. VOA News. https://www.voanews.com/south-central-asia/pakistans-china-built-nuclear-reactor-starts-operation

13. Shepherd, W. (2019, October 3). What China is Really Up to in Africa. Forbes.

https://www.forbes.com/sites/wadeshepard/ 2019/10/03/what-china-is-really-up-to-in-africa/ exports RE. This will increase land scarcity and economic incentives to overlook current protections. Existing policies need be updated and strengthened as the pressures to exploit the environment increase.

14. Bennun L, van Bochove J, Ng C, Fletcher C, Wilson D, Phair N, et al. (2021). Mitigating biodiversity impacts associated with solar and wind energy development: guidelines for project developers. IUCN, International Union for Conservation of Nature.

https://doi.org/10.2305/IUCN.CH.2021.04.en.

15. Conkling TJ, Loss SR, Diffendorfer JE, Duerr AE, Katzner TE. (2021). Limitations, lack of standardization, and recommended best practices in studies of renewable energy effects on birds and bats. Conserv Biol;35:6476. https://doi.org/10.1111/cobi.13457.

16. Sonter LJ, Dade MC, Watson JEM, Valenta RK. (2020). Renewable energy production will exacerbate mining threats to biodiversity. Nat Commun;11:6-11 https://doi.org/10.1038/s41467-020-17928-5.

17. Abass AZ, Pavlyuchenko DA. (2019). The exploitation of western and southern deserts in Iraq for the production of solar energy. Int J Electr Comput Eng;9:4617-24. https://doi.org/10.11591/ijece.v9i6.pp4617-4624.

18. Bouba, M. "North Africa Nomadic Indigenous Knowledge: Ayt Khabach Nomads Urban Challenges in Southeastern Morocco." The Palgrave Handbook of African Education and Indigenous Knowledge. Palgrave Macmillan, Cham, 2020. 265-277.

https://doi.org/10.1007/978-3-030-38277-3 13

19. Essalhi A, Essalhi M, Toummite A. (2016). Environmental Impact of Mining Exploitation: A Case Study of Some Mines of Barite in the Eastern Anti-Atlas of Morocco. J Environ Prot (Irvine, Calif);07:1473-82. https://doi.org/10.4236/jep.2016.711124.

20. African Development Bank Group (AfDB). (2014). Ouarzazate Solar Power Station Project II: Summary Environmental and Social Impact Assessment. https://www.afdb.org/fileadmin/uploads/afdb/Documents/Environmental-and-Social-Assessments/Morocco - Ouarzazate Solar Power Station Project II ESIA Summary.pdf

21. Dahir (Royal Decree) no. 1-95-154 of 18 Rabii I 1416 (16 August 1995) promulgating Law no. $10-95$ on water Official State Gazette no. 4325 of 20 September 1995 http://gis.nacse.org/rewab/docs/Royal Decree No 195-154 Promulgating Law on Water EN.pdf

22. United States International Trade Administration. (2020-12-10). Morocco - Country Commerical Guide Water. https://www.trade.gov/country-commercialguides/morocco-water

23. International Energy Agency (IEA). (2018). Data and Statistics: Electricity Balance Table. Accessed 2021-0831: https://www.iea.org/data-and-statistics/datatables/?country=MOROCCO\&energy=Electricity\&year $=2$ $\underline{018}$

\section{Notes}

\section{Climate Compatible Growth (CCG) programme: CCG} is funded by the UK's Foreign Development and Commonwealth Office (FCDO) to support investment in sustainable energy and transport systems to meet development priorities in the Global South.

\section{Author Information}

Affiliations: Energy and Power Group, Department of Engineering Science, University of Oxford, Oxford, United Kingdom.

Corresponding author: aniq.ahsan@stx.ox.ac.uk 